\title{
Constant that improve (double) factorial
}

\section{CRISTINEL MORTICI and CHAO-PING CHEN}

\section{ABSTRACT.}

The purpose of this paper is to discuss and refine some recent results of Bauer [Remark on Stirling's formula and on approximations for the double factorial, Mathematical Intelligencer, 29, (2007),10-14] and Brede [On the convergence of the sequence defining Euler's number Mathematical Intelligencer, 27, (2005), 6-7].

DEPARTMENT OF MATHEMATics

VALAHIA UNIVERSITY OF TÂRGOVIŞTE

UNIRII 18, 130082 TÂRGOVIŞTE, ROMANIA

E-mail address: cmortici@valahia.ro

HENAN POLYTECHNIC UNIVERSITY

SCHOOL OF MATHEMATICS AND INFORMATICS

Jiaozuo City 454003, Henan Province, People's Republic of China

E-mail address: chenchaopinge sohu.com 